\title{
HILGARDIA
}

A Journal of Agricultural Science Publisbed by the California Agricultural Experiment Station

\section{TEMPERATURE AND PLANT RESPONSES TO PAPER AND PLASTIC PROTECTORS ON CANTALOUPES}

\author{
C. A. SHADBOLT \\ and \\ O. D. MecoY
}

UNIVERSITY OF CALIFORNIA - BERKELEY, CALIFORNIA 


\section{TEMPERATURE AND PLANT RESPONSES TO PAPER AND PLASTIC PROTECTORS ON CANTALOUPES ${ }^{1,2}$}

\section{A. SHADBOLT ${ }^{3}$ and O. D. McCOY}

\section{INTRODUCTION}

WHEN WARM-SEASON PLANTS are grown during the winter months, some means of microclimatic manipulation becomes essential. This is the case in the production of cantaloupes in the desert areas of the southwestern United States. At El Centro in Imperial Valley, for instance, the average maximum in January of 1959 was $73.3^{\circ}$ and the average minimum was $39.8^{\circ} \mathrm{F}$. The soil temperature varies from a maximum of about $75^{\circ}$ to a minimum of about $45^{\circ}$ F. According to Knott (1957), ${ }^{5}$ the optimum temperature for cantaloupe growth is a monthly average of $90^{\circ}$ during the day and $60^{\circ}$ during the night. The optimum soil germination temperature is about $90^{\circ} \mathrm{F}$. It is obvious, then, that conditions existing in this area during January are far from ideal for the germination and growth of cantaloupe plants.

In contrast to the use of plant protectors in many other areas of the country, those used during the winter season in the desert areas of California remain in place for as long as three months. Cantaloupes planted during December remain under the protection of the shelters for nearly half of their life span. Any device employed under such conditions must meet certain requirements in order to be of value. Conditions should be such that rapid growth occurs and vigorous and hardy plants are produced. Environmental modifications which would create conditions for the plants more ideal than those naturally occurring would be: increased daytime air temperature, but not in excess ; maximum increase in nighttime air temperature, hence protection from frost; increase in soil temperature; and maintenance of relative humidity at moderate levels. In addition to the conditions which relate directly to plant growth, shelters must also provide protection from wind and blowing sand.

\footnotetext{
${ }^{1}$ Submitted for publication February 8, 1960.

${ }^{2}$ Paper No. 1214, University of California Agricultural Experiment Station, Riverside, California.

${ }^{3}$ Assistant Olericulturist, Department of Vegetable Crops, Riverside.

${ }^{4}$ Assistant Specialist, Department of Vegetable Crops, Imperial Valley Field Station, El Centro.

"See "Literature Cited" for citations, referred to in the text by author and date.
} 
In order for a shelter to provide any degree of frost protection, it is necessary that heat accumulation under the cover during the day be greater than that which is lost through the cover during the night. This loss is brought about by convection, conduction, and radiation. It is logical to assume that a film with a relatively low transmission of infrared would reduce the loss by radiation and would therefore retain more heat at night than one with a high transmission. This, however, is not necessarily the case. Waggoner (1958) compared two films, an acrylonitrile-styrene copolymer, which transmitted only one-third of the infrared radiation, and polyethylene, which transmitted seven-eighths of the long-wave radiation. Initially, no differences

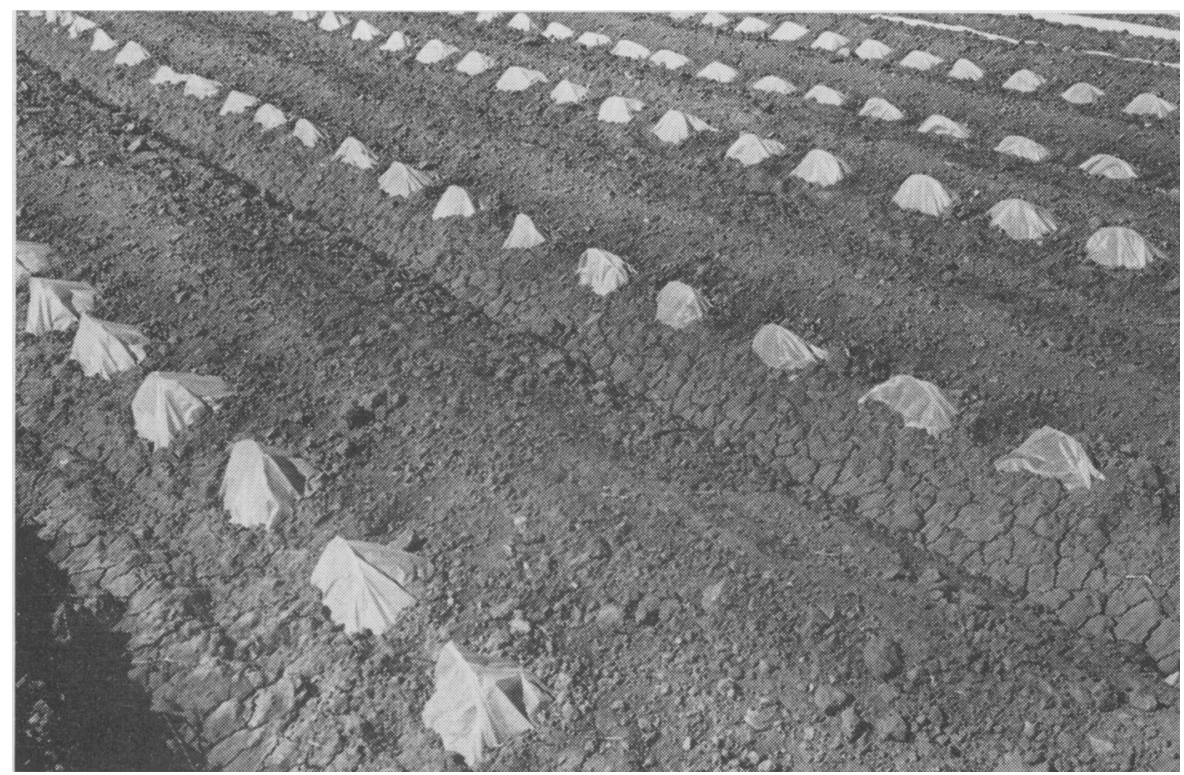

Fig. 1. Conventional caps, used in Imperial Valley on cantaloupe plants, formed from $18 \times 20$-inch sheets of glassine. The caps are placed on the south side of sloping beds.

in the frost protection afforded by these two films could be measúred in the field. At the time of these measurements, dew had formed on all the films. This water film was estimated to transmit only 1 per cent of the infrared radiation, and accounted for the similarity of response of the two films. Measurements of heat flow through the films before and after dew formation confirmed this belief. It is apparent from this that the transmission properties of the film are not critical, provided there is a layer of moisture condensate on it.

In Imperial Valley, the early melons are planted during December and January and require protection from frosts and wind until about the middle of March. The conventional method of protection during this period is the individual glassine paper cap, which is applied over the seeded row before irrigation is supplied. During February, the caps are removed, the plants thinned and weeded, and the caps replaced. They are usually removed completely by the middle of March. This method of protection provides, under 
most conditions, an environment satisfactory to the growth of the plants. A small measure of frost protection is achieved; the day and night temperatures are both increased; soil temperature is increased; and protection is afforded from wind and blowing sand. Cantaloupes are planted on the south side of large, sloping beds, which in itself has a beneficial effect on the microclimate. A small acreage each year is given the added protection of brush. This consists of kraft paper supported by palm fronds, arrowweed, or lath, and wire, erected on the north side of the rant and sloping over the row about $30^{\circ}$ from the vertical. This type of structure has been shown by Hart and Zink (1957) to reduce the nocturnal heat flow from the soil and to increase insolation. These workers showed that there was very little difference between several brushing materials, as indicated by temperature measurement and plant response.

\section{METHODS}

For several seasons, experiments have been conducted at the University of California Imperial Valley Field Station near Holtville to evaluate a number of materials for use as individual caps and continuous row covers, as well as to determine the benefit derived from the addition of brush to these covers. One object of this study was to determine the relative frost protection provided by different types of covers and various materials. Concurrent with the greatly increased use and interest in plastics for agricultural applications, polyethylene and vinyl films were evaluated for use as individual and continuous plant covers.

In all these trials, variety SR-91 cantaloupe was used for the test. In order to obtain a uniform seeding rate, seed for all treatments was sown with a Planet Junior planter on the south side of standard sloping beds. The beds were spaced seven feet apart. When individual caps were used, they were spaced two feet apart in the row. Six to eight weeks after planting, the caps were lifted and the plants thinned to two per cap, and the caps were replaced. When continuous row covers were used, plants were thinned to one plant to every foot of row. In order to measure the early growth of the seedlings, plant samples were drawn before thinning and the weights were determined. In those experiments where samples were drawn after thinning, an additional row other than the harvest row was used.

All the individual caps, referred to as standard caps, were constructed in the field from sheets of plastic or paper $18 \times 20$ inches in size, and formed over wickets made from twenty-four-inch wire or wood splints. The continuous covers were formed by placing twelve-gauge wire in arcs every two feet over the seeded row. The film was pulled taut and anchored by placing soil on both edges.

Ventilation of the continuous plastic covers was accomplished by initially punching small holes about one foot apart in the film on the south side of the covers. These holes were increased in size and the ends of the covers were opened as the plants grew. This method was satisfactory during the early part of the season, but as the holes were enlarged the strength of the structure was impaired, and in a few instances tearing occurred during windy periods which resulted in damage to the plants. As a result of the experiments con- 
[Vol. 30, No. 9

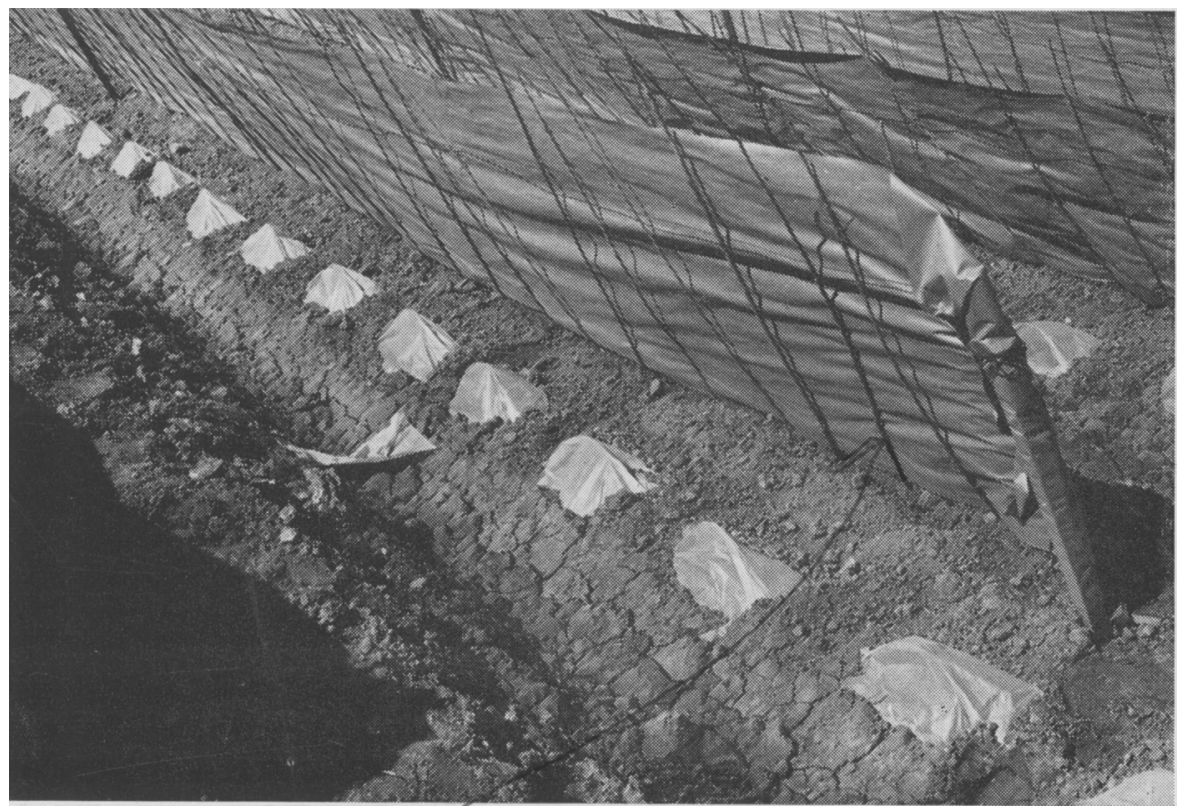

Fig. 2. Kraft brush placed over glassine caps. The brush is supported by arrowweed.

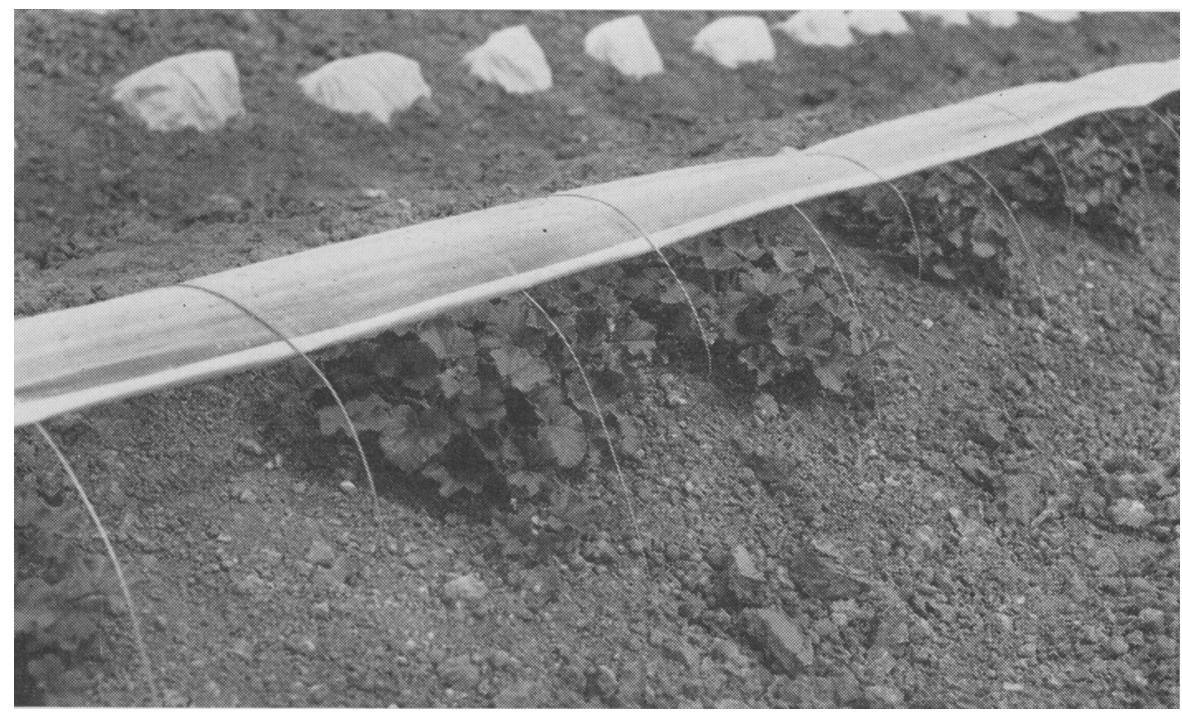

Fig. 3. A continuous polyethylene cover just prior to removal. The opening on the south side of the cover has been gradually increased in size until the plants are about half uncovered. This cover was constructed from thirty-six-inch perforated 1.5-mil film, using twelve-gauge wire thirty-eight inches long. 
ducted, it has become very obvious that ventilation of plastic materials is essential shortly after emergence of the plants. The main problem has been to supply adequate ventilation without destroying the strength and rigidity of the structure or the protective properties of the covers. A system whereby the covers were opened during favorable periods and closed during cold or windy periods was found to be impractical. The method of ventilation which seemed most satisfactory and economical was the use of a wire on the outside of the cover adjacent to the wire beneath the cover. The entire south side of the cover was then lifted from the soil surface. The size of the opening was increased as the season progressed. The tension of the film between the outer and inner wires was sufficient to hold it in place, even under adverse conditions.

The individual caps, whether paper or plastic, were ventilated by punching a small hole on the southeast corner shortly after emergence of the seedlings. When the covers were lifted for the thinning operation, they were replaced over the plants with the east end open.

\section{SEASON 1955-56}

An experiment was set up in this season to determine the value of standard glassine caps when used alone and in conjunction with brush. A treatment using parchment paper ${ }^{6}$ as continuous row covers was also included. These were approximately ten inches wide at the base, and about twelve inches high.

The covers were applied over the seeded row and the field was irrigated on December 16, 1955. Four replications and a sixty-five-foot harvest row were used.

The plants were thinned and weeded on February 22. Plant samples were taken at the time of thinning and again about six weeks later. Temperature measurements under the covers were taken with Auto-Lite recording thermographs. The temperature-sensitive elements were placed one inch from the ground level, and were shaded from the sun by means of small cardboard shields. Ambient air temperature was recorded approximately three feet above ground level.

\section{Results}

Various plant responses to the three treatments are shown in table 1. At the time of thinning, the plants covered with caps and brush were significantly larger than plants from the other two treatments, as measured by the fresh weight. The plants under the parchment were significantly larger than those under the glassine. At this time, the moisture content of the plants under the continuous parchment covers was significantly higher than in those under the individual glassine paper caps, whether with brush or without.

Difficulty was experienced with the continuous caps at the time of thinning. Because of the deterioration of the parchment paper, it was impossible to lift the caps to thin and weed the crop and replace them in good condition. The plants were therefore damaged considerably by exposure at this time. This injury is reflected by the fresh weight of the plants which were sampled on May 3. The weight of plants from the continuous parchment covers was

\footnotetext{
${ }^{6}$ Supplied by Kalamazoo Vegetable Parchment Company.
} 
less, but not significantly less than that from the standard glassine caps. The plant weight from the standard glassine caps with the addition of brush was significantly higher than that from the glassine or the continuous parchment covers.

The total yield of marketable melons in standard crates per acre and the gross returns in dollars are also shown in table 1 . The yield of melons from the brushed areas was significantly higher than from the other two treatments, resulting in an increase of about fifty crates of marketable melons per acre. These treatments also matured melons earlier than the nonbrushed ones. Using the interpolated date at which 50 per cent of the melons were harvested, the brushed melons were eight days earlier than the nonbrushed ones.

TABLE 1

RESPONSE OF CANTALOUPE PLANTS TO VARIOUS PROTECTIVE DEVICES- 1956

\begin{tabular}{|c|c|c|c|c|c|c|c|}
\hline & $\begin{array}{c}\text { Average } \\
\text { fresh wt. } \\
\text { per plant } \\
2 / 24 / 56 \\
\text { (grams) }\end{array}$ & $\begin{array}{c}\text { Per cent } \\
\text { moisture } \\
\text { in plants } \\
2 / 24 / 56\end{array}$ & $\begin{array}{c}\text { Average } \\
\text { fresh wt. } \\
\text { per plant } \\
5 / 3 / 56 \\
\text { (grams) }\end{array}$ & $\begin{array}{c}\text { Total } \\
\text { marketable } \\
\text { yield per } \\
\text { acre } \\
\text { (crates) }\end{array}$ & $\begin{array}{l}\text { Date at } \\
\text { which } \\
\text { one-half } \\
\text { yield } \\
\text { removed }\end{array}$ & $\begin{array}{l}\text { Returns } \\
\text { per acre } \\
\text { (dollars) }\end{array}$ & $\begin{array}{c}\text { Per cent } \\
\text { plants } \\
\text { damaged } \\
\text { by frost } \\
2 / 24 / 56\end{array}$ \\
\hline Standard glassine.. & .480 & 90.34 & 272.3 & 129.09 & $7 / 15$ & 374.86 & 67.13 \\
\hline Standard glassine plus brush. & .851 & 89.84 & 527.6 & 191.64 & $7 / 7$ & 814.92 & 24.69 \\
\hline Continuous parchment...... & .576 & 92.74 & 236.1 & 106.27 & $7 / 15$ & 272.49 & 27.26 \\
\hline L.S.D. (.05) & .258 & 1.61 & 111.26 & 46.23 & & & 27.73 \\
\hline L.S.D. $(.01) \ldots$ & .375 & 2.34 & 160.00 & 66.49 & & & 39.88 \\
\hline
\end{tabular}

The per-acre returns were calculated from the number of melons harvested per plot and the prices quoted at the shipping point, El Centro, on the day of harvest. The brushed treatments realized more than double the returns of either the standard glassine caps or the continuous covers. This difference was undoubtedly brought about by the increased early yield which occurred from the brushed treatments.

The daily maximum and minimum temperatures under the covers are shown in figure 4 . The maximum temperatures under all the covers were generally higher than the outside air temperature. The highest maximum temperatures were recorded under the caps which had the additional protection of brush. Here the temperature read $112^{\circ} \mathrm{F}$. on February $7,40^{\circ}$ above the outside air temperature. Readings under this treatment were more often about 10 to $15^{\circ}$ above the outside temperature. The continuous parchment covers showed the least temperature gain over air temperature. In fact, on several days during the month, the maximum temperatures under continuous covers were lower than the outside air temperature. This occurred particularly on days of high maximums.

The minimum temperatures showed a somewhat different picture. The continuous caps, despite the relatively low heat accumulation during the day, provided the highest night temperatures, ranging up to $14^{\circ}$ above outside air temperature. The standard glassine cap provided the least increase, with temperatures up to $3^{\circ}$ above the outside temperature. 


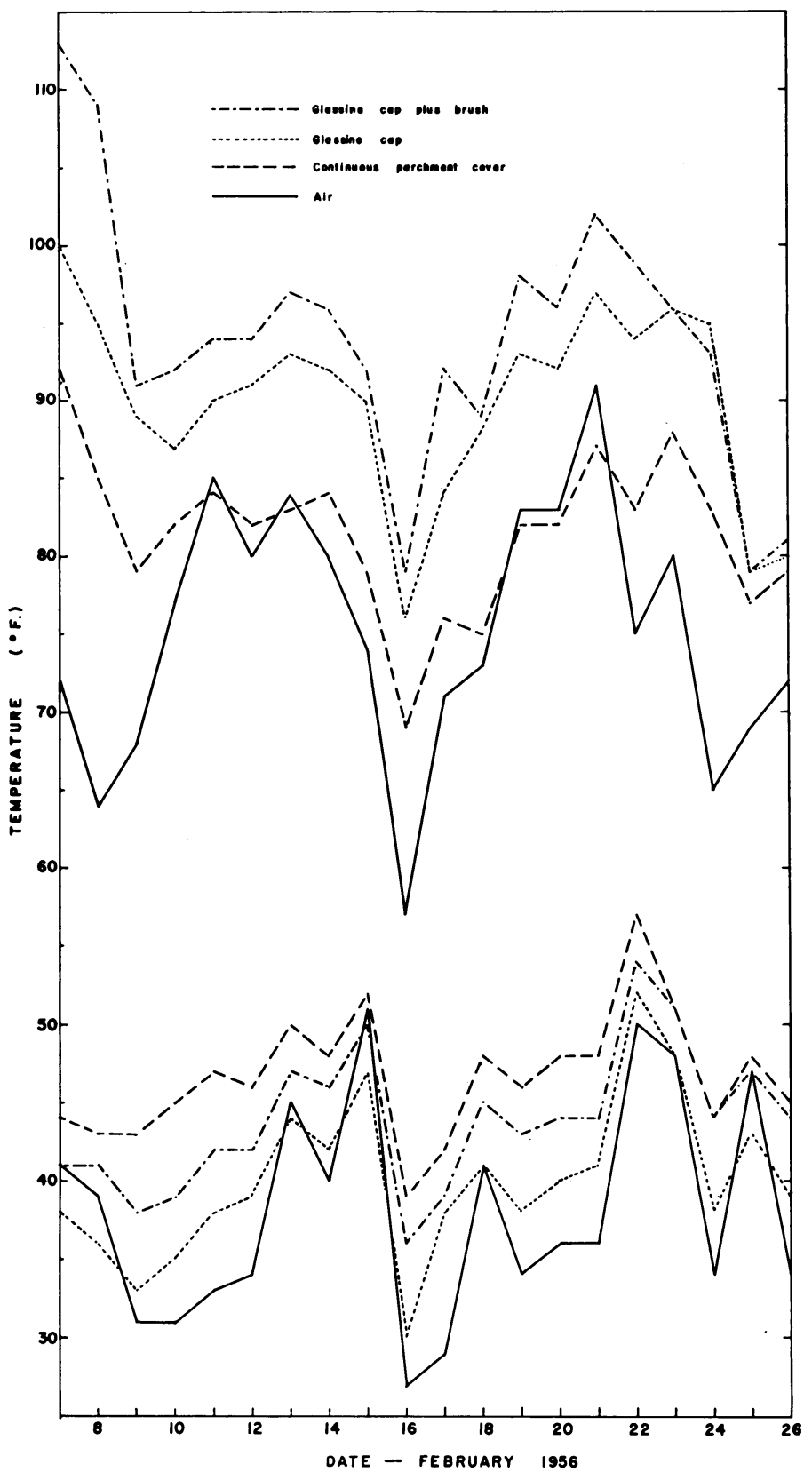

Fig. 4. Maximum and minimum air temperatures under three covers, February 1956. Temperatures under the caps were measured two inches above the soil surface. The air temperature was measured three feet above the soil surface. 
During the spring of 1956 , there were two periods in which the minimum outside air temperature was recorded below $32^{\circ}$. On February 16 , the minimum reading was $27^{\circ}$. This resulted in considerable injury to some of the plants. Counts of damaged plants were made on February 24 in each of the treatments, and by this method the actual protection afforded by each cover could be determined. The per cent of plants damaged by frost is shown in table 1. It may be seen that the least amount of protection was provided by the standard glassine caps, with about 67 per cent of the plants damaged. The caps with the brush and the continuous covers were not significantly different in this respect, and showed about 25 and 27 per cent of the plants damaged, respectively.

\section{SEASON 1956-57}

Experiments in this season were set up to compare and evaluate three types of plant covers: standard caps from $18 \times 20$-inch sheets, large caps from $20 \times 22$-inch sheets, and continuous row covers, all with and without the addition of brush. The individual caps were constructed from glassine, clear polyethylene, and aluminum-impregnated polyethylene, both 1.5 mils (.0015 inch) in thickness. The continuous covers were constructed from the two polyethylene materials, with a base of 9 inches. The brushed treatments were replicated twice; the nonbrushed treatments, four times.

Cantaloupes were planted, the covers applied, and first irrigated on December 19, 1956. Plants were thinned and weeded on February 14, 1957. Plant samples were removed on three dates and dry weights were determined. Yield data were not collected because of severe mosaic infection late in the season.

\section{Results}

The average dry weight per plant, as sampled at three dates, is shown in table 2. According to the analysis of variance of the weights at all three dates, there was a highly significant over-all difference between the brushed and nonbrushed treatments. In all cases, the brushed treatments produced the largest plants. The analysis also showed that the large caps afforded no advantage over the small caps at any of the dates. In most cases, the continuous clear polyethylene covers produced plants which were larger than those from any other treatment.

Aluminum polyethylene was generally unsatisfactory, but especially so when brush was not used. The plants produced under this film were somewhat chlorotic and etiolated, indicating insufficient light transmission through the film.

Air and soil temperature readings were taken under the various nonbrushed treatments throughout January 17 and 18, 1957, using thermocouples and potentiometer. During the period just prior to sunrise, and from 1:00 to 3:00 P.M., readings were made at frequent intervals to determine the minimum and maximum temperatures which occurred during these periods. The results are shown in table 3 . Both the minimum and maximum air temperatures indicate very little advantage of the large individual cap

\footnotetext{
${ }^{7}$ Supplied by Union Carbide Plasties Company.
} 
TABLE 2

AVERAGE DRY WEIGHT PER PLANT-1957

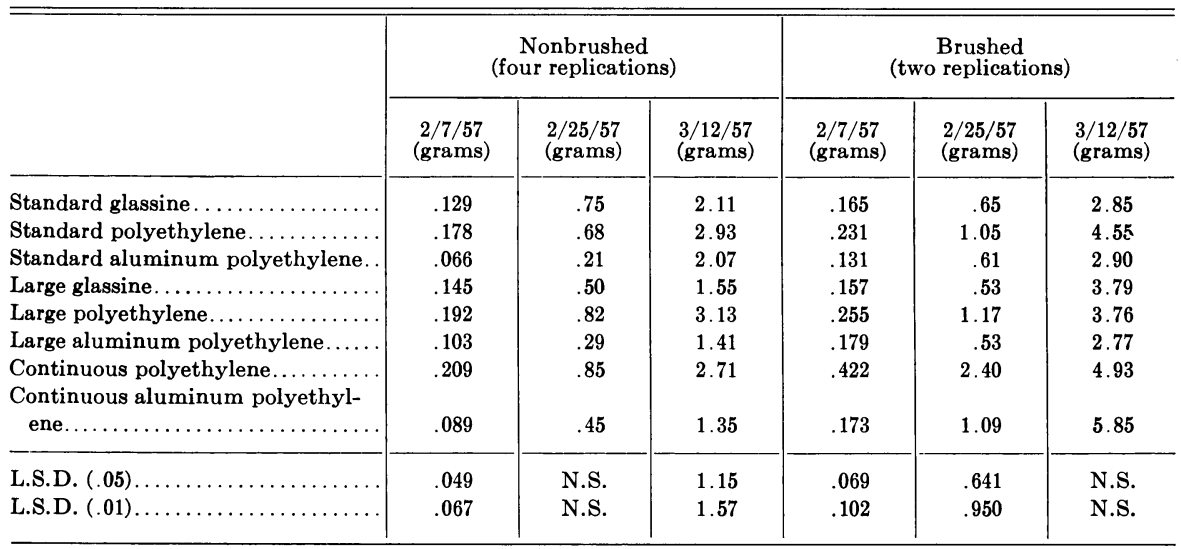

TABLE 3

MINIMUM AND MAXIMUM AIR AND SOIL TEMPERATURES (DEGREES F.) UNDER SEVERAL NONBRUSHED TREATMENTS-1957

\begin{tabular}{|c|c|c|c|c|c|c|c|}
\hline & \multicolumn{4}{|c|}{ Air temperature } & \multicolumn{3}{|c|}{$\begin{array}{l}\text { Soil temperature at } \\
\text { two-inch depth }\end{array}$} \\
\hline & \multicolumn{2}{|c|}{$1 / 17 / 57$} & \multicolumn{2}{|c|}{$1 / 18 / 57$} & \multicolumn{2}{|c|}{$1 / 17 / 57$} & \multirow{2}{*}{$\frac{1 / 18 / 57}{\text { Min. }}$} \\
\hline & Min. & Max. & Min. & Max. & Min. & Max. & \\
\hline Standard glassine. & 40.0 & 94.5 & 38.5 & 97.0 & 46.0 & 68.0 & 45.5 \\
\hline Large glassine.. & $\ldots$ & 99.0 & 38.0 & 100.0 & $\ldots$ & $\ldots$ & $\ldots$ \\
\hline Standard polyethylene. & 37.5 & 97.0 & 36.5 & 100.0 & 44.0 & 68.5 & 44.0 \\
\hline Large polyethylene...... & 37.0 & 102.0 & 36.5 & 105.0 & $\ldots$ & $\ldots$ & $\ldots$ \\
\hline Continuous polyethylene $\ldots \ldots \ldots \ldots$ & 41.5 & 93.0 & 39.0 & 96.0 & 50.5 & 75.0 & 49.0 \\
\hline Standard aluminum polyethylene... & 39.5 & 83.0 & 36.5 & 94.0 & 45.5 & 65.0 & 45.5 \\
\hline Large aluminum polyethylene...... & 39.5 & 85.0 & 37.5 & 94.0 & $\ldots$ & $\ldots$ & $\ldots$ \\
\hline Continuous aluminum polyethylene & 40.5 & 80.5 & 38.5 & 87.0 & 48.0 & 78.0 & 44.0 \\
\hline No cover..................... & $\ldots$ & 68.5 & 32.0 & 69.0 & $\ldots$ & 69.5 & 41.0 \\
\hline
\end{tabular}

over the smaller standard cap. Minimum temperatures under the aluminum and the clear polyethylene continuous covers were from 1 to $4^{\circ} \mathrm{F}$. higher than under the corresponding individual standard caps. Both the standard aluminum and clear polyethylene individual caps showed minimum temperatures about $2^{\circ}$ lower than those with the standard glassine caps. The minimum air temperature under the continuous polyethylene showed only from 0.5 to $1.5^{\circ}$ advantage over the standard glassine. Soil temperatures at the two-inch depth also showed the highest minimum temperatures to occur under the continuous polyethylene covers. Soil temperatures under the large individual caps were not obtained. 


\section{SEASON 1957-58}

An experiment was set up this season, using standard polyethylene individual caps, continuous polyethylene row covers, and standard glassine caps with and without a low, sixteen-inch brush. Two continuous row covers were used, one with a fourteen-inch base and the other with an eight-inch base. Clear polyethylene film twenty-eight inches wide and 1.5 mils in thickness was used in both cases.

\section{Results}

The emergence of the cantaloupe plants under the continuous covers and the glassine caps plus brush was significantly faster than under the individual glassine or polyethylene caps. These data are shown in table 4 .

TABLE 4

THE EMERGENCE OF SEEDLINGS AND THE AVERAGE DRY WEIGHT PER PLANT AT THREE DATES EARLY IN THE GROWING SEASON-1958

\begin{tabular}{|c|c|c|c|c|}
\hline & \multirow{2}{*}{$\begin{array}{c}\text { Emergence } \\
\text { per six- } \\
\text { foot row } \\
1 / 8 / 58\end{array}$} & \multicolumn{3}{|c|}{ Dry weight per plant } \\
\hline & & $\begin{array}{l}1 / 29 / 58 \\
\text { (grams) }\end{array}$ & $\begin{array}{l}2 / 14 / 58 \\
\text { (grams) }\end{array}$ & $\begin{array}{l}2 / 25 / 58 \\
\text { (grams) }\end{array}$ \\
\hline Standard glassine. & 1.4 & .055 & .128 & .449 \\
\hline Standard polyethylene........ & 2.9 & .066 & .198 & .419 \\
\hline Standard glassine plus sixteen-inch brush. & 9.6 & .076 & .164 & .477 \\
\hline Continuous polyethylene, narrow base... & 10.6 & .073 & .266 & .823 \\
\hline Continuous polyethylene, wide base... & 10.8 & .064 & .312 & .831 \\
\hline L.S.D. (.05) & 2.1 & N.S. & .101 & .284 \\
\hline L.S.D. $(.01) \ldots \ldots \ldots \ldots \ldots \ldots \ldots \ldots$ & 3.0 & N.S. & .142 & .399 \\
\hline
\end{tabular}

Plant samples were taken at three dates during the early growth of the melons, and the dry weights were determined, as may also be seen in table 4 . Differences between treatments in dry weight were not significant at the first sampling date, but the continuous covers tended to produce larger plants. At the other two dates, however, both the continuous covers produced plants significantly larger than those from the standard glassine caps. The margin of increased size of plants under the continuous covers compared with the other treatments increased with each sampling date.

The nitrate-nitrogen content on a dry-weight basis of plants removed at the first sampling date was determined by a method outlined by Johnson and Ulrich (1950). It may be seen from table 5 that the treatments can be placed into groups according to the level of nitrate in the plants. Relatively low nitrate levels were found in the plants protected by the individual covers. There were no significant differences among the individual treatments. The level of nitrate under the continuous polyethylene covers was significantly (.05) higher than under any of the individual covers. There was a close direct relationship between the nitrate content and the moisture content of the plants at the first sampling date. The moisture content of the plants under the plastic materials ranged from 92.8 to 94 per cent, while under the glassine covers the content was 88.7 and 89.6 per cent. The difference in 
moisture content of plants under the glassine and the polyethylene covers was highly significant. These differences did not occur at the later sampling dates.

The number of melons one-half inch and larger in diameter which had been set by April 9, 1958, is presented in table 6. It may be seen that there was a significantly higher number of fruits set under the wide-based continuous

TABLE 5

THE MOISTURE AND NITRATE-NITROGEN (DRY-WEIGHT BASIS) CONTENT OF THE PLANTS-1958

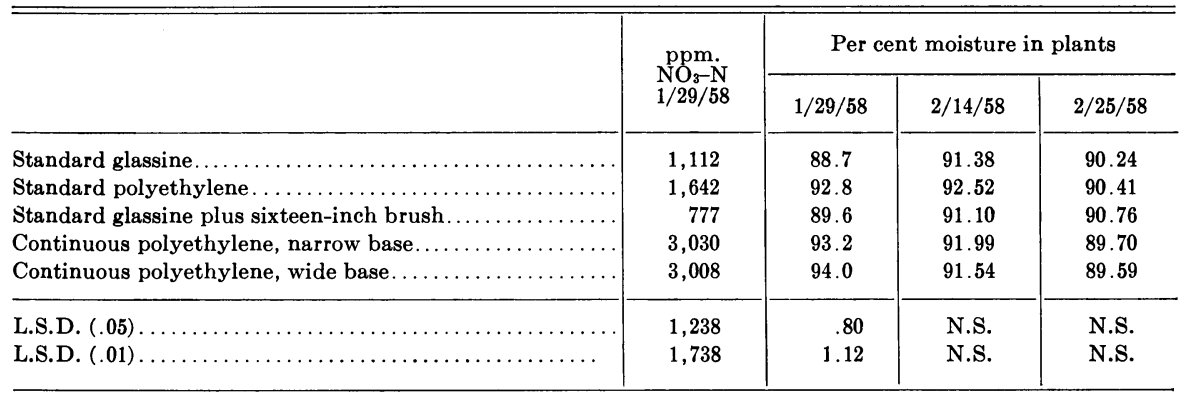

TABLE 6

EARLY FRUIT SET, YIELD, AND RETURNS PER ACRE-1958

\begin{tabular}{|c|c|c|c|c|}
\hline & $\begin{array}{c}\text { Number } \\
\text { melons set } \\
\text { per plot } \\
4 / 9 / 58\end{array}$ & $\begin{array}{c}\text { Marketable } \\
\text { yield per acre, } \\
\text { first pick } \\
5 / 21 / 58 \\
\text { (crates) }\end{array}$ & $\begin{array}{c}\text { Total } \\
\text { marketable } \\
\text { yield } \\
\text { per acre } \\
\text { (crates) }\end{array}$ & $\begin{array}{l}\text { Returns } \\
\text { per acre } \\
\text { (dollars) }\end{array}$ \\
\hline Standard glassine.. & 1.5 & 3.24 & 261.5 & $1,169.10$ \\
\hline Continuous polyethylene, narrow base... & 12.0 & 7.24 & 218.0 & 982.40 \\
\hline Continuous polyethylene, wide base..... & 42.2 & 13.30 & 201.6 & 900.55 \\
\hline L.S.D. $(.05) \ldots \ldots \ldots \ldots \ldots \ldots \ldots \ldots \ldots$ & 11.5 & 5.11 & 43.2 & N.S. \\
\hline L.S.D. $(.01) \ldots \ldots \ldots \ldots \ldots \ldots$ & 16.1 & 7.35 & 60.6 & N.S. \\
\hline
\end{tabular}

polyethylene cover as compared with the narrow-based cover. Both the continuous covers showed a high set compared with the individual caps.

The yield of melons from the first pick on May 21 was significantly greater from the continuous polyethylene cover with the wide base than from any other treatment, which undoubtedly reflects the early fruit set recorded from this treatment. The increased early yield was not great enough, however, to be reflected in the returns per acre, which were based upon the shipping-point prices on the day the melons were harvested. The total yield of melons was significantly lower from the continuous polyethylene covers and the glassine caps plus brush than from the other two individual caps. The low yield from the continuous covers probably resulted in part from the difficulty experienced in providing adequate ventilation prior to cover removal. Many of the plants suffered wind burn at this time. 
Measurements of air temperature and soil temperature at two depths were made on January 23, 1958, with a potentiometer-thermocouple arrangement, and are presented in table 7 . In most cases, readings were taken from two replications.

The highest minimum air temperature of $36^{\circ} \mathrm{F}$. was recorded under the glassine caps with brush. This was $5.5^{\circ}$ above outside temperature. The continuous polyethylene cover with narrow base provided an average of $3^{\circ}$ advantage, whereas the one with wide base provided $4^{\circ}$ protection on this

TABLE 7

MAXIMUM AND MINIMUM TEMPERATURES (DEGREES F.) OF THE AIR AND SOIL UNDER SEVERAL COVERS-JANUARY 23, 1958

\begin{tabular}{|c|c|c|c|c|c|c|c|}
\hline & \multirow{3}{*}{$\begin{array}{l}\text { Repli- } \\
\text { cation }\end{array}$} & \multirow{2}{*}{\multicolumn{2}{|c|}{ Air temperature }} & \multicolumn{4}{|c|}{ Soil temperature } \\
\hline & & & & \multicolumn{2}{|c|}{ One-inch depth } & \multicolumn{2}{|c|}{ Two-inch depth } \\
\hline & & Min. & Max. & Min. & Max. & Min. & Max. \\
\hline \multirow{2}{*}{ Standard glassine $\ldots \ldots \ldots \ldots \ldots \ldots$} & A & 33.5 & 113.0 & 43.5 & 88.5 & 46.0 & 84.5 \\
\hline & B & 31.0 & 115.0 & 43.0 & $\ldots$ & 45.0 & $\ldots$ \\
\hline \multirow[t]{2}{*}{ Standard polyethylene $\ldots \ldots \ldots \ldots \ldots$} & $\mathbf{A}$ & 33.0 & 107.5 & 42.5 & 86.0 & 44.5 & 75.0 \\
\hline & B & 31.0 & 105.0 & 43.0 & $\ldots$ & 44.5 & $\ldots$ \\
\hline \multirow{2}{*}{ Standard glassine plus brush........ } & A & 36.0 & 120.0 & 45.0 & 94.0 & $\ldots$ & 87.0 \\
\hline & B & 36.0 & 131.0 & 44.5 & $\ldots$ & 44.5 & $\ldots$ \\
\hline \multirow{2}{*}{$\begin{array}{l}\text { Continuous polyethylene, narrow } \\
\text { base } \ldots \ldots \ldots \ldots \ldots \ldots \ldots \ldots \ldots \ldots\end{array}$} & A & 34.0 & 100.0 & 45.0 & 90.5 & 46.5 & 77.5 \\
\hline & B & 33.0 & 105.0 & 42.0 & $\cdots$ & 44.5 & $\cdots$ \\
\hline \multirow[t]{2}{*}{ Continuous polyethylene, wide base } & A & 34.0 & 105.0 & 44.5 & 99.0 & 47.5 & 91.5 \\
\hline & B & 35.0 & 105.5 & 43.5 & $\cdots$ & 46.5 & $\cdots$ \\
\hline No cover.. & . & 30.5 & 71.0 & $\ldots$ & $\ldots$ & 41.0 & 66.0 \\
\hline
\end{tabular}

particular night. Both the standard glassine and polyethylene caps showed only $1.5^{\circ}$ of protection. The maximum day temperatures under all covers were at least $30^{\circ}$ above outside air temperature. The brushed treatments resulted in the highest maximum temperature as well as the highest minimum. Here the temperature reached $131^{\circ}$ at one location.

The trend in the minimum soil temperature at the one-inch depth followed very closely that of the minimum air temperature, with the highest minimum being recorded from the brushed treatment. The continuous polyethylene provided slightly higher minimum temperatures than did the individual caps. The maximum soil temperatures at the one-inch depth showed much greater differences than the minimums. The highest temperature occurred under the wide-based continuous polyethylene cover. This was $8.5^{\circ}$ higher than under the narrow-based cover. Likewise, at the two-inch soil depth, the highest minimum and maximum temperatures were recorded under the wide-based continuous polyethylene. The average minimum temperatures under the other covers were from 1.5 to $2.5^{\circ}$ lower than under the continuous polyethylene cover. The maximum temperatures under the standard and 
the narrow-based continuous polyethylene covers were the lowest, with 75 and $77.5^{\circ}$, respectively. The maximum temperature at the two-inch depth under the uncovered area was considerably lower than from any of the treated areas.

\section{SEASON 1958-59}

The experiment of 1959 was set up mainly to evaluate several materials as both individual caps and continuous row covers, and to determine the value of perforations in the continuous plastic covers.

The field was first irrigated on December 23, 1958, following application of the covers. Four replications were used, and the harvest plot consisted of one row forty feet long. Individual caps of glassine, clear and highdensity polyethylene, and vinyl films, and continuous covers of the three plastic materials were included in the trial. High-density polyethylene, sometimes referred to as linear polyethylene, is opaque white in color and is considerably more brittle or "papery" than natural polyethylene film. All individual caps except conical glassine ${ }^{8}$ were constructed from sheets $18 \times 20$ inches in size, according to the method used for standard glassine caps. The continuous covers were from film thirty-six inches wide, and were constructed with a base of twenty-two inches and a height of six to nine inches. The clear polyethylene and vinyl films were 1.5 mils, the high-density polyethylene was 2.0 mils in thickness. Perforations were three-sixteenths of an inch in diameter, spaced $2 \times 3$ inches throughout the center eighteen inches of the film.

Ventilation of the continuous unperforated plastic covers and the plastic individual caps was begun on January 16, shortly after emergence. At this time, small holes were punched in the individual caps, and in the continuous covers at about one-foot intervals. Three weeks later, larger holes were made in all the covers. The covers were removed completely on March 12.

\section{Results}

The emergence of seedlings under the continuous covers was much faster than under the individual caps, as may be seen in table 8. In fact, most of the plants had emerged in the continuous treatments before any had emerged in the individual treatments.

Plant samples were taken from the field on February 6, and fresh weight, dry weight, per cent moisture, and nitrate-nitrogen content were determined. These are also shown in table 8 . Both the fresh weight and the dry weight indicated that the plants under the continuous covers were significantly larger than those under the individual covers at this early date. There were significant differences among the continuous covers according to the L.S.D. in both fresh and dry weights. When the analysis of variance for treatments was broken down, however, the greater part of the variance occurred in the comparisons between the individual and the continuous covers, and indicated no significance among the continuous covers.

The per cent moisture in the plants showed some striking differences. The plants under all the continuous covers were significantly higher in moisture

\footnotetext{
${ }^{8}$ Supplied by Paxton Products Company, Riverside, California.
} 
content than those under all the individual caps. Considering only the individual caps, the two glassine caps showed significantly lower moisture content than did the three plastic caps.

Measurements have shown that the relative humidity under the plastic continuous covers is maintained at about 90 per cent during the day. Perforations in the film reduced the humidity by only a few percentage points. The relative humidity under the glassine caps by comparison was maintained at about 25 per cent during the same period.

TABLE 8

RESPONSE OF CANTALOUPE PLANTS DURING EARLY GROWTH TO VARIOUS PROTECTIVE DEVICES-1959

\begin{tabular}{|c|c|c|c|c|c|}
\hline & \begin{tabular}{|c} 
Emergence \\
per six- \\
foot row \\
$1 / 8 / 59$
\end{tabular} & $\begin{array}{c}\text { Fresh } \\
\text { weight } \\
\text { per plant } \\
2 / 6 / 59 \\
\text { (grams) }\end{array}$ & $\begin{array}{c}\text { Dry } \\
\text { weight } \\
\text { per plant } \\
2 / 6 / 59 \\
\text { (grams) }\end{array}$ & $\begin{array}{c}\text { Per cent } \\
\text { moisture } \\
\text { in plants } \\
2 / 6 / 59\end{array}$ & $\begin{array}{l}\mathrm{NO}_{3}-\mathrm{N} \\
\text { dry } \\
\text { weight } \\
2 / 6 / 59 \\
\text { (ppm.) }\end{array}$ \\
\hline Standard glassine. & 0.00 & 2.24 & .232 & 89.67 & 3,338 \\
\hline Standard vinyl. . & 0.00 & 2.52 & .209 & 91.72 & 5,878 \\
\hline Standard high-density polyethylene. . & 0.25 & 2.89 & .252 & 91.10 & 4,784 \\
\hline Standard clear polyethylene........... & 0.00 & 2.36 & .194 & 91.69 & 5,147 \\
\hline Conical glassine $\ldots \ldots \ldots \ldots \ldots \ldots \ldots \ldots$ & 0.00 & 1.75 & .184 & 89.32 & 2,537 \\
\hline Continuous polyethylene $\ldots \ldots \ldots \ldots \ldots \ldots \ldots \ldots$ & 10.75 & 10.50 & .618 & 94.09 & 8,515 \\
\hline Continuous polyethylene, perforated $\ldots \ldots \ldots \ldots \ldots \ldots$ & 7.25 & 8.36 & .532 & 93.61 & 7,975 \\
\hline Continuous vinyl. $\ldots \ldots \ldots \ldots \ldots \ldots \ldots \ldots \ldots \ldots$ & 10.75 & 8.33 & .501 & 93.76 & 7,503 \\
\hline Continuous vinyl, perforated $\ldots \ldots \ldots \ldots$ & 10.75 & 11.54 & .713 & 93.78 & 7,438 \\
\hline Continuous high-density polyethylene.... & 22.25 & 11.18 & .666 & 93.98 & 8,543 \\
\hline L.S.D. (.05). & N.S.* & 2.66 & .160 & .94 & 1,426 \\
\hline L.S.D. (.01).. & N.S.* & 3.60 & .216 & 1.26 & 1,926 \\
\hline
\end{tabular}

* Analysis of variance performed on the five continuous treatments only.

The nitrate-nitrogen content of the plants sampled on February 6 showed that a significantly greater uptake occurred in the plants under the continuous covers than in those under the individual caps. Of the individual caps, those of plastic materials showed a higher nitrate content than the glassine paper covers. The correlation coefficient of nitrate content and per cent moisture in the plants was .929 , indicating that greater nitrate uptake occurred in the fast-growing, more succulent plants.

Counts of the fruit which measured more than one inch in diameter were taken on March 31. These data are presented in table 9. At this time, there were practically no melons one inch and larger on the plots covered by individual caps. By comparison, the set on the continuous covers ranged from eighteen to thirty-two melons per forty feet of row. These data, as expected, correspond very closely to the weight of melons harvested in the first two picks, May 7 and May 11, 1959, which is shown in table 9. These two picks produced from twenty-four to thirty-two pounds of melons per plot (fortyeight to sixty-four Jumbo crates per acre) from the continuous covers, compared to less than five pounds (ten crates) from the individual covers. The total yield showed no significant differences between treatments.

In order to obtain an estimate of the returns per acre, the weight of melons harvested was converted to Jumbo crates of melons per acre, based on an 
average crate weight of 77.5 pounds. The returns were then calculated, based on the Los Angeles terminal market prices for each size of melon on the day that the harvest took place. Shipping-point prices could not be used, as there were no quotations at the time of the early picks. The returns per acre showed no significant differences.

As the harvest was terminated at an early date, May 25, the price throughout the picking period was maintained at a relatively high level. Had the price dropped earlier, or had the harvest occurred later, the increased early

TABLE 9

FRUIT SET AND YIELD OF CANTALOUPES-1959

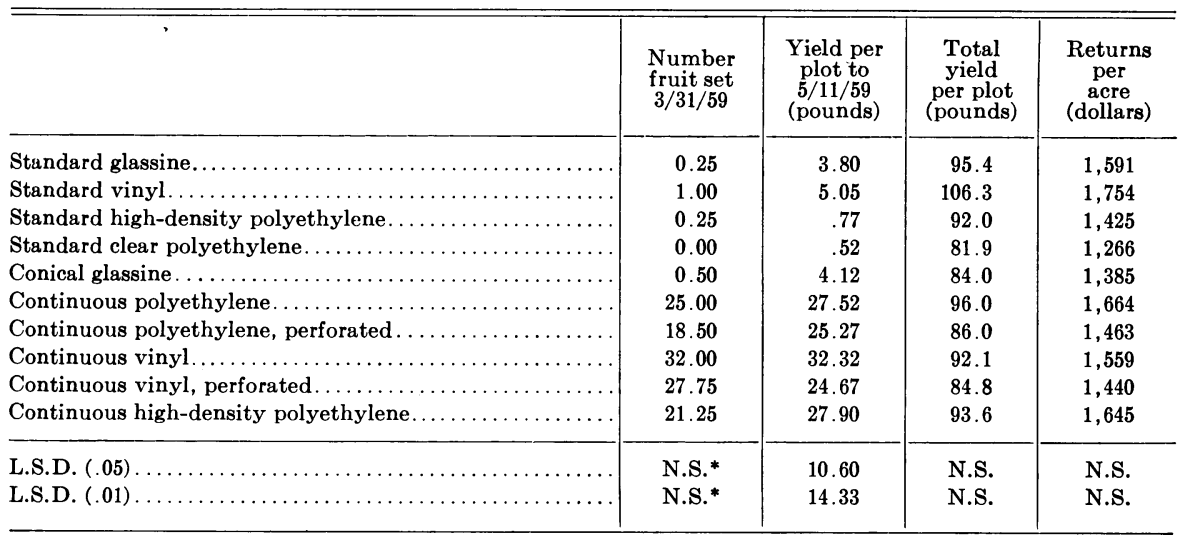

* Analysis of variance performed on the five continuous treatments only.

yield from the continuous covers would have been expected to be reflected in the returns per acre.

As in the previous year, no frost occurred during the melon-growing season. This made it impossible to evaluate the covers under actual frost conditions. Temperatures were taken through a twenty-four-hour period, however, using thermocouples, and the minimum temperatures recorded in both soil and air are shown in table 10. Maximum temperatures varied greatly as to the time at which they occurred for the various treatments, and therefore they could not be definitely ascertained from the number of readings taken. The treatments can be divided into two groups according to the minimum air temperatures as measured two inches above the soil surface under the covers. All the individual covers, paper or plastic, showed minimum temperatures in the range 1 to $3.5^{\circ} \mathrm{F}$. above the minimum outside air temperature. The individual cap constructed from 1.5-mil vinyl film showed the lowest minimum temperature, with $1^{\circ}$ above outside air temperature. The cap from 2-mil high-density polyethylene provided the greatest increase over the outside air temperature. The continuous covers showed minimum air temperatures ranging from 5.5 to $7.5^{\circ}$ above outside air temperature. The two continuous perforated covers, made of clear polyethylene and vinyl film, showed the lowest temperatures.

Minimum soil temperatures reflected the same trends as the air temperatures. The minimum soil temperatures at one inch ranged from 49 to $51^{\circ}$ 
and 53.5 to $55.5^{\circ}$, respectively, for the individual and the continuous covers. The minimum temperatures at the two-inch depth ranged about 1 to $2^{\circ}$ higher than at one inch. The minimum temperatures in open uncovered soil were 47 and $50.5^{\circ}$, respectively, for the one- and two-inch depths.

\section{DISCUSSION}

The use of thirty-six-inch brushing in addition to conventional glassine caps was found to be quite advantageous. In the 1955-56 season, this treatment provided greater early growth and greater yield than the glassine caps alone. The daytime temperatures measured under the caps with brush were rela-

TABLE 10

MINIMUM SOIL AND AIR TEMPERATURES (DEGREES F.) UNDER SEVERAL PAPER AND PLASTIC COVERS-FEBRUARY 6, 1959

\begin{tabular}{|c|c|c|c|c|}
\hline & \multirow{2}{*}{$\begin{array}{l}\text { Repli- } \\
\text { cation }\end{array}$} & \multirow{2}{*}{$\begin{array}{l}\text { Minimum air } \\
\text { temperature }\end{array}$} & \multicolumn{2}{|c|}{ Minimum soil temperature } \\
\hline & & & One-inch & Two-inch \\
\hline Standard glassine..... & $\begin{array}{l}\text { A } \\
\text { B }\end{array}$ & $\begin{array}{l}40.0 \\
39.0\end{array}$ & $\begin{array}{l}50.5 \\
51.0\end{array}$ & $\begin{array}{l}52.5 \\
53.0\end{array}$ \\
\hline Standard vinyl $\ldots \ldots \ldots \ldots \ldots \ldots \ldots \ldots \ldots$ & $\begin{array}{l}\text { A } \\
\text { B }\end{array}$ & $\begin{array}{c}38.5 \\
\ldots\end{array}$ & $\begin{array}{l}49.0 \\
\ldots .\end{array}$ & $\begin{array}{l}\ldots \\
\ldots\end{array}$ \\
\hline Standard high-density polyethylene......... & $\begin{array}{l}\text { A } \\
\text { B }\end{array}$ & $\begin{array}{l}41.0 \\
40.5\end{array}$ & $\begin{array}{l}51.0 \\
49.5\end{array}$ & $\begin{array}{l}52.5 \\
51.0\end{array}$ \\
\hline Standard clear polyethylene $\ldots \ldots \ldots \ldots \ldots \ldots$ & $\begin{array}{l}\text { A } \\
\text { B }\end{array}$ & $\begin{array}{l}39.0 \\
39.0\end{array}$ & $\begin{array}{l}50.5 \\
49.0\end{array}$ & $\begin{array}{l}52.0 \\
51.0\end{array}$ \\
\hline Conical glassine ........... & $\begin{array}{l}\text { A } \\
\text { B }\end{array}$ & $\begin{array}{c}39.5 \\
\ldots\end{array}$ & $\begin{array}{l}51.0 \\
\ldots\end{array}$ & $\begin{array}{l}52.0 \\
\ldots\end{array}$ \\
\hline Continuous polyethylene $\ldots \ldots \ldots \ldots \ldots \ldots$ & $\begin{array}{l}\text { A } \\
\text { B }\end{array}$ & $\begin{array}{l}44.5 \\
45.0\end{array}$ & $\ldots$ & $\begin{array}{l}54.5 \\
56.0\end{array}$ \\
\hline Continuous polyethylene, perforated.......... & $\begin{array}{l}\text { A } \\
\text { B }\end{array}$ & $\begin{array}{l}43.0 \\
\ldots\end{array}$ & $\begin{array}{c}54.0 \\
\ldots\end{array}$ & $\begin{array}{c}56.0 \\
\ldots\end{array}$ \\
\hline Continuous vinyl. ............... & $\begin{array}{l}\text { A } \\
\text { B }\end{array}$ & $\begin{array}{l}45.0 \\
45.0\end{array}$ & $\begin{array}{l}55.5 \\
54.0\end{array}$ & $\begin{array}{l}57.0 \\
56.0\end{array}$ \\
\hline Continuous vinyl, perforated.......... & $\begin{array}{l}\text { A } \\
\text { B }\end{array}$ & $\begin{array}{l}43.5 \\
\ldots .\end{array}$ & $\begin{array}{c}53.5 \\
\ldots\end{array}$ & $\begin{array}{l}55.0 \\
\ldots\end{array}$ \\
\hline Continuous high-density polyethylene......... & $\begin{array}{l}\text { A } \\
\text { B }\end{array}$ & $\begin{array}{l}45.0 \\
45.0\end{array}$ & $\begin{array}{l}54.5 \\
54.5\end{array}$ & $\begin{array}{l}56.5 \\
56.0\end{array}$ \\
\hline No cover.................... & $\begin{array}{l}\text { A } \\
\text { B }\end{array}$ & $\begin{array}{l}37.5 \\
\ldots\end{array}$ & $\begin{array}{l}47.0 \\
47.0\end{array}$ & $\begin{array}{l}50.5 \\
50.5\end{array}$ \\
\hline
\end{tabular}

tively high compared with the other treatments. The highest temperature measured under this treatment was $131^{\circ}$ F., recorded on January 23, 1958. It is felt that temperatures in this range would be detrimental to plant growth, although no obvious heat injury symptoms occurred. The minimum night temperature under the brush was up to $10^{\circ}$ higher than the outside air temperature. In the 1956-57 season, brushing was used in conjunction 
with several individual and continuous covers. Almost without exception, the plants under the brush were larger than those without brush. In many cases, this increase in plant size was more than twofold.

Continuous covers provided, in general, better emergence, faster growth, and earlier fruit set and harvest than individual caps. Paper used for the construction of continuous covers was unsatisfactory because of tearing brought about by the physical breakdown of the paper on exposure to the weather. Both polyethylene and vinyl films, 1.5 mils in thickness, resisted tearing, provided they were applied taut over wire wickets. When wooden splints were used on sloping beds, the moisture condensation inside the cover caused them to collapse.

Temperaturewise, the continuous polyethylene covers showed several advantages over the conventional glassine caps. The maximum temperatures under these covers were higher than the outside air temperature, but generally not so high as with glassine caps. The minimum temperatures measured under unperforated polyethylene film recorded on February 6, 1959, were 7.0 to $7.5^{\circ} \mathrm{F}$. above outside air temperature; on January 23, 1958, the advantage was $4^{\circ}$; on January $18,1957,7^{\circ}$ of protection was obtained. The minimum temperatures under the standard glassine caps were 2.5, 2.0, and $6.5^{\circ}$ at each date, respectively, above outside air temperature. It may be concluded that greater frost protection is afforded by the continuous polyethylene covers than by the conventional glassine caps. It must be remembered, however, that because of lack of actual frost conditions, these data were determined for the most part at temperatures slightly above $32^{\circ} \mathrm{F}$.

When minimum air temperatures were taken over a period of several days, such as was done in the 1955-56 season, it was very evident that the difference in temperature under any one cover compared with outside air temperature varied considerably from day to day. In general, the difference between cover temperature and outside temperature was greater on days of low minimums. This would indicate that a better estimate of potential frost protection could be obtained on a night of a low rather than a high minimum.

The maximum soil temperature measured under the continuous polyethylene covers was up to $10^{\circ} \mathrm{F}$. higher at the one-inch depth, and $7^{\circ}$ higher at the two-inch depth, than under the conventional glassine caps. This greater heat accumulation in the soil during the day undoubtedly accounted for the greater protection which the continuous covers provided during the night. These higher soil and air temperatures, as well as being advantageous as far as frost protection was concerned, were undoubtedly important factors responsible for the greater and earlier plant growth which occurred under the continuous covers.

The shape of the continuous row covers appeared to influence the environment within the cover. In 1957-58, both wide- and narrow-based polyethylene continuous row covers were used. The soil area under the wide cover was nearly twice that under the narrow cover. On the day that temperature measurements were made, there was only a slight advantage of the wide over the narrow with regard to maximum and minimum air temperatures. A greater difference occurred, however, in the soil temperatures in favor of the wide-based cover. Under the wide cover, the maximum soil temperature 
at the one-inch depth was $8.5^{\circ} \mathrm{F}$. warmer, and at two inches, $14^{\circ}$ warmer than under the narrow cover. These higher soil temperatures constitute a considerable advantage in that they more nearly approach optimum conditions for cantaloupe growth. Despite the fact that differences in early plant growth and yield between the two covers were slight in this particular case, observations on small trials other than those reported indicate that the wide cover is superior to the narrow. The wide cover will also provide more growing space for a prostrate plant such as the cantaloupe.

In both the 1957-58 and 1958-59 seasons, the plants which were protected by plastic showed significantly greater moisture content than those protected by glassine paper. There are two factors which might be expected to account for this difference in moisture content. First, the relative humidity under the plastic covers remained at above 85 to 90 per cent throughout the day. The relative humidity under the paper caps decreased from very high levels during the night and early morning hours to as low as 15 per cent during the afternoon. Secondly, the temperature, particularly the soil temperature, was found to be several degrees warmer under the plastic than under the paper materials. Raleigh (1941), working with muskmelons, found that the uptake of water was increased greater than threefold when the culture solution temperature was increased from $50^{\circ}$ to $65^{\circ} \mathrm{F}$. Likewise, Schroeder (1939) measured a similar increase in water uptake by the cucumber when the root temperature was increased from $60^{\circ}$ to $70^{\circ} \mathrm{F}$. It is very probable that both high relative humidity and high soil temperature were responsible for the marked degree of succulence in the plants under the plastic covers.

The succulence of plants produced is an important consideration in the use of any covering material. Plants which are in a nonhardened state are more susceptible to injury by diseases and adverse weather conditions. Frost injury, for instance, would be expected to occur at a higher temperature if the plants were tender and succulent. The relatively high moisture content of the plants and the excessive moisture accumulation under the plastic covers serve to emphasize the need for adequate and timely ventilation of these covers.

In the last two seasons of the experiment, there were also recorded marked differences in the levels of nitrate-nitrogen in the plants under the various treatments. There appeared to be a direct relationship between the nitrate content and the moisture content of the plants, in that those treatments which produced plants high in nitrate, namely, the continuous plastic covers, also produced the plants highest in moisture. The correlation between these two factors existed throughout all the treatments, particularly in the data of 1959. It would appear, therefore, that the factors which caused the high moisture content were also involved in increasing the nitrate content. High soil temperatures which were measured under the continuous covers would be expected to cause increased root growth and increased physiological activity, both of which could contribute to the increased uptake of water and nitrate.

Perforations in the plastic continuous covers did not appear to offer any advantage over nonperforated films from the standpoint of plant response 
or relative humidity. The minimum temperatures under the perforated films were 1.5 to $2^{\circ} \mathrm{F}$. lower than under similar covers not perforated. It is believed that perforations are desirable, despite the apparent reduction in potential frost protection, as they would probably provide some measure of ventilation or gas exchange during the early stages of growth prior to the actual lifting of the covers.

In order to evaluate and compare the several types of covers used in these trials, the economics of their use must be considered. Data have been presented which show the returns per acre which were derived from the various types of covers. The per-acre costs of material for each of the general types of covers have been determined for plantings on rows spaced seven feet apart, as they are grown in the Imperial Valley. At the time of writing, the cost to the grower for 1.5-mil polyethylene three feet wide, including wires, is $\$ 80$ to $\$ 90$ per acre $(6,220$ linear feet). The wire can be used for several years, and its cost will vary with size and type. If wider film is used, the cost will increase proportionately. The cost of the standard glassine cap plus wooden splints is about $\$ 30$ per acre (3,110 caps). Several prefabricated glassine caps are now available and are used to some extent. The cost of these is approximately $\$ 60$ per acre. The use of brushing involves the expenditure of at least $\$ 150$ per acre for material. None of these figures include application costs, which vary widely. It may be stated, however, that application cost of the prefabricated cap would be somewhat less than for the standard cap which is formed in the field. It appears at this time that polyethylene may be applied somewhat faster than individual caps and lends itself to possible mechanical application. In some cases, polyethylene has been salvaged and re-used a second year. In this case, the cost of the material would be prorated over two years. The time required for the thinning and weeding operation, and the extent of replacement because of wind damage, must also be evaluated for each type of cover if the relative costs are to be determined.

\section{CONCLUSIONS}

1. Brush used in addition to standard glassine caps provided greater early growth and greater yields than the caps alone. Both day and night temperatures were higher than with nonbrushed treatments, and up to $10^{\circ}$ F. potential frost protection was obtained. The use of brush in conjunction with plastir continuous and individual covers showed similar advantages.

2. Plastic films, when used as individual plant covers, showed no advantage over paper materials. Minimum temperatures under the plastic films were usually slightly lower than under comparable glassine covers.

3. Continuous plastic covers were, in general, superior to individual covers. The physical properties of paper made this material impractical use as continuous covers in the area in which the testing was done. Continuous plastic covers increased emergence and early plant growth. and provided earTier fruit set and greater, earlier yield than individual caps. Minimum temperatures which varied from 4 to $7.5^{\circ}$ above outside air temperature were recorded under continuous covers compared with 2 to $6^{\circ}$ under conventional glassine caps. 
4. No difference in plant response could be measured under perforated and nonperforated continuous plastic covers. Slightly lower minimum temperatures were measured when the covers were perforated.

5 . Wide continuous covers covering a maximum of soil area were found superior to narrow and higher covers.

6. Plants under plastic covers were found to have a higher moisture and nitrate-nitrogen content than plants under paper covers.

7. After emergence of the plants, ventilation of the plastic covers to reduce humidity and moisture condensation was found to be essential.

\section{LITERATURE CITED}

HART, S. A., and F. W. ZINK

1957. Brushing and brushing materials for frost protection. Amer. Soc. Hort. Sci. $69: 475-79$.

Johnson, C. M., and Albert Ulrich

1950. Determination of nitrate in plant material. Anal. Chem. 22:1526-29.

KNOTT, J. E.

1957. Handbook for vegetable growers. John Wiley \& Sons, Inc., New York. Pages 7, 8.

RALEIGH, G. J.

1941. The effect of culture solution temperature on the water uptake and wilting of the muskmelon. Amer. Soc. Hort. Sci. 38:487-88.

SchROEDER, R. A.

1939. The effect of root temperature upon the absorption of water by the cucumber. Mo. Ag. Expt. Sta. Res. Bul. 309.

WAGgONER, PAUL E.

1958. Protecting plants from the cold. The principles and benefits of plastic shelters. Conn. Ag. Expt. Sta. Bul. 614. 
The journal Hilgardia is published at irregular intervals, in volumes of about 600 pages. The number of issues per volume varies.

Subscriptions are not sold. The periodical is sent as published only to libraries, or to institutions in foreign countries having publications to offer in exchange.

You may obtain a single copy of any issue free, as long as the supply lasts; please request by volume and issue number from:

\section{Agricultural Publications \\ Room 207 University Hall \\ 2200 University A venue \\ Berkeley 4, California}

The limit to nonresidents of California is 10 separate issues on a single order. A list of the issues still available will be sent on request.

In order that the information in our publications may be more intelligible it is sometimes necessary to use trade names of products or equipment rather than complicated descriptive or chemical identifications. In so doing it is unavoidable in some cases that similar products which are on the market under other trade names may not be cited. No endorsement of named products is intended nor is criticism implied of similar products which are not mentioned. 